\title{
Jornalismo audiovisual de qualidade: um conceito em construção
}

Beatriz Becker

\section{Resumo}

O artigo propõe uma reflexão sobre parâmetros de qualidade nas práticas do telejornalismo e do webjornalismo audiovisual, em função dos processos de hibridização de suportes e linguagens mediados pelas tecnologias digitais; questionando o jornalismo como forma de conhecimento. Num momento em que as atividades de ver TV e acessar a internet se misturam, o texto apresenta ainda referências teóricas para a construção do conceito jornalismo audiovisual e para estudos das narrativas noticiosas na televisão e na web marcadas pela multimidialidade e pela interatividade.

Palavras-chave:

Parâmetros de Qualidade, Narrativas Híbridas, Telejornalismo, Webjornalismo Audiovisual, Análise Televisual

Sobre a autora

Prof. Dra. do

Departamento

de Expressão e

Linguagens e do

Programa de Pósgraduação da Escola

de Comunicação-

UFRJ. Possui

Doutorado (2002)

e mestrado (1992)

em Comunicação e

Cultura pela Escola

de Comunicação da

UFRJ (1992), e pósdoutorado realizado na

PUC-SP (2005)

beatrizbecker@uol.com.br

\section{High quality audio-visual journalism: a concept under construction}

\section{Abstract}

The article proposes a reflection about parameters of quality in the practices of TV news and of audiovisual webjournalism, in function of the trials of hybridization of supports and languages mediated by the digital technologies; questioning Journalism as form of knowledge. At a time when activities like watching TV and accessing the internet are mixed, the text also presents theorical references for the construction of the concept audiovisual journalism and for studies of the news narratives on television and Web marked by the multimediality and by the Interactivity.

Key words:

Quality Parameters, Hybrid Narratives, TV news, Audiovisual Webjournalism; Televisual Analysis. 


\section{Do mito da imagem ao diálogo televisual}

A imbricação entre a televisão e a informática produz inovações tecnológicas que atravessam todas as experiências individuais e coletivas. As enunciações jornalísticas da televisão e da internet são processos de des-construção e re-construção de referências e de identidades, territórios simbólicos onde se trava a estratégica batalha cultural do nosso tempo marcada pela visualidade tecnológica constituintes das narrativas midiáticas. (MARTIN-BARBERO, 2001). Há, porém, uma crítica a ilusória plenitude informativa na sociedade contemporânea, que sugere uma sensação de estarmos quase presentes ao acontecimento veiculado pela imagem e pela retórica repetitiva, simplificadora e veloz das mensagens, e não por conteúdos jornalísticos pertinentes à compreensão da realidade histórica. Segundo Sodré ( 2008, p.19, p.60), a rede tecnológica confunde-se com o processo comunicacional resultando na imagem-mercadoria e um novo regime de visibilidade pública regido pela midiatização. ParaVattimo (1992, p.22-23), o aumento da circulação das informações até à simultaneidade da reportagem televisiva ao vivo, a construção do mundo com imagens, é a principal característica da contemporaneidade. Em vez de avançar para a autotransparência, a sociedade da comunicação avançou para aquela que se pode chamar a "fabulação do mundo" porque as imagens do mundo que nos são fornecidas pelos media constituem a própria objetividade do mundo e não apenas interpretações diferentes de uma determinada realidade (VATTIMO, 1992, p.31). Refletir sobre as imagens e seus efeitos de sentidos, usos e apropriações, porém, é questão complexa, cada vez mais indissociável da crítica a uma perversa hegemonia do audiovisual, enquanto a polissemia da imagem é negligenciada pela academia (MARTIN-BARBERO, 2001, p.19). Em acordo com Machado (2001,15-22), as imagens não são responsáveis pela ausência de valores éticos ou pela ausência de diversidade de representações de identidades e culturas nas mídias, até porque é possível afirmar que, ao mesmo tempo, em que a imagem está na origem de toda a escritura e a escrita verbal é tão somente uma forma altamente especializada de iconografia, também é verdade que a imagem nunca deixou de ser uma certa modalidade da escritura. (MACHADO, 2001, p.2). E análises de suas significações podem sugerir mergulhos mais profundos na experiência e no pensamento, nos libertando da crença do poder da palavra como única fonte da verdade (Machado,2001,p.6-33). Hoje, não há apenas uma superabundância da circulação de imagens, mas de informação em diferentes suportes e linguagens, até mesmo na Internet são acessados majoritariamente conteúdos construídos por palavras e não por imagens. Nos sites jornalísticos mais visitados no país verifica-se ${ }^{1}$ que os conteúdos

1 "Telejornalismo na Era Digital". Trabalho apresentado no $6^{\circ}$ Encontro Nacional de Pesquisadores em Jornalismo - SBPJor 2008. 
audiovisuais jornalísticos correspondem a menos de $10 \%$ das notícias das homepages. Os estudos das narrativas jornalísticas na TV e na Internet sugerem uma desmistificação do poder do texto audiovisual de modelar a vida social e homogeneizar todos os sentidos na atualidade. Isso não significa negar a realidade do mundo ofertada pela mídia, assumir as imagens como espelho do real ou rejeitá-las como simulacros e representações falsas, mas poder reconhecer que notícias que utilizam a linguagem audiovisual e recursos multimídia são constituídas por modos de dizer, de perceber e de intervir na experiência e na vida social, mas seus efeitos de sentidos também dependem do modo como interagimos com a TV e fazemos uso do computador. As narrativas jornalísticas audiovisuais, tanto na TV, quanto na internet são aqui nomeadas práticas de jornalismo audiovisual porque ao identificar transformações nas narrativas dos telejornais e apontar características discursivas do webjornalismo audiovisual observase que essas distintas narrativas têm sofrido influências mútuas e passam por um processo de hibridização mediadas pelas tecnologias digitais. As atividades de ver TV e acessar internet, e mais especificamente de assistir ao telejornal e de acompanhar as notícias audiovisuais publicadas na web, começam a se fundir. (MURRAY apud CIRNE, FERNANDES, PÔRTO, 2009, p.104). É necessário reconhecer que há maneiras distintas de trabalhar o material audiovisual e modos singulares de organizar idéias e fazer uso de um conjunto de características narrativas e de recursos técnicos, compreensíveis e facilmente identificáveis pelo receptor e/ou usuário associados a dispositivos técnicos distintos que reconhecemos como gêneros ${ }^{2}$ discursivos. A convergência tecnológica e a tendência à utilização simultânea de diferentes suportes e linguagens na construção das narrativas jornalísticas audiovisuais, porém, promovem um apagamento dessas diferenças. Os novos formatos de notícias que incorporam a linguagem audiovisual e os recursos multimídia demandam um aprofundamento da reflexão crítica sobre a aplicação do conceito de gênero com características narrativas estáveis e sobre as práticas do telejornalismo e do webjornalismo audiovisual, o que exige uma elaboração inovadora de referências teóricas. A introdução da dimensão da análise televisual associada à semiologia dos discursos sociais e à teoria crítica do discurso, especialmente a partir das contribuições de Casetti e Chio ( 1999), Pinto ( 1995 ) e Fairclough (2001), constitui-se em uma perspectiva teórica relevante no estudo das narrativas jornalísticas audiovisuais. Essa estratégia se justifica porque existe uma carência significativa de estudos e de obras de cunho teórico-metodológico, voltadas ao exame dos processos de significação e sentido no campo específico da produção televisual (DUARTE, 2004, p.5) e também do

${ }^{2}$ Assume-se a definição do conceito de gênero discursivo apresentada por Mikhail Bakhtin, porque é uma teoria consistente, flexível e adaptável às análises do audiovisual contemporâneo. Como afirma Bakhtin: "a riqueza e diversidade dos gêneros discursivos é imensa, porque as possibilidades da atividade humana são inesgotáveis e porque em cada esfera da práxis existe todo um repertório de gêneros discursivos que se diferencia e cresce à medida que se desenvolve e se complexifica a própria esfera." (BRAIT, 2005, p.155) 
hipertexto. E na sociedade contemporânea não há competência Nesse sentido,

a partir de comunicativa se não se dominam os códigos da expressão audiovisual. O ideal é que os telespectadores- usuários sejam capazes não apenas de compreendê-los, mas também de se expressar mediante eles para não serem condenados a ser simples receptores passivos e acríticos, intervindo de maneira ativa na percepção através da seleção e da interpretação, interagindo com o que desperta seu interesse. Sodré (2008, p.115-116) reconhece que a imagem e os seus desdobramentos sintéticos nas tecnologias do virtual podem ter um grande potencial referente à dimensão sensorial do processo cognitivo porque o hipertexto é um instrumento de expressiva importância nos processos de aprendizagem que oferece ao estudante um papel ativo na construção/ reconstrução do conhecimento, podendo estimular atividades de pesquisa e de associação de informações. Em acordo com Ferré (1994, p.106), educar para a reflexão crítica supõe compreender o sentido explícito e implícito das informações e das histórias e, sobretudo, ser capaz de estabelecer relações coerentes e críticas entre o que aparece na tela e a realidade do mundo fora dela. E o sentido de imediatez proporcionado pelas imagens pode ser compensado pelo sentido da reflexão propiciado pelo diálogo (FERRÉ, 1994, p.116-117). Nesse sentido, a partir de parâmetros de TV e jornalismo de qualidade, reafirma-se a necessidade de oferecer subsídios para distinguir entre as reportagens televisivas e os conteúdos audiovisuais noticiosos publicados no ciberespaço que guardam alguma inventividade estética e temática, e as notícias que não oferecem relatos jornalísticos pertinentes à compreensão da realidade histórica. Nesse mundo mediado pelas tecnologias digitais, onde a comunicação tem papel central e a experiência da realidade social é constituída por combinações de imagens e palavras nos textos jornalísticos, revela-se a necessidade de refletir sobre a função do jornalismo como forma de conhecimento na atualidade.

\section{Jornalismo como forma de conhecimento na contemporaneidade}

O conhecimento nunca é reflexo ou espelho da realidade, é sempre uma tradução, seguida de uma reconstrução. Mas, essas traduções são também um risco de erro e muitas vezes o maior erro é pensar que a idéia é a realidade (MORIN, 2003), assim como confundir as notícias com uma realidade multidimensional. A notícia é apresentada ao público como sendo a realidade e, mesmo que o público perceba que se trata apenas de uma versão da realidade, dificilmente terá acesso aos critérios de decisão que orientaram a equipe de jornalistas para construí-la. A elaboração das notícias está diretamente relacionada a lógica do mercado de 
produção, distribuição e consumo de informações. Mas, a definição de notícia ainda é problemática porque também envolve o ethos jornalístico e a cultura profissional. A notícia é, simultaneamente, um registro da realidade social e um produto dela, e as características de cada meio influem na estruturação das notícias (Vizeu 2005, p.13). Há, porém, diferentes e complementares teorias das notícias e ainda não podemos apontar a existência de uma teoria completa. Alsina (2009, p.14-15) propõe que "a notícia é uma representação social da realidade cotidiana, gerada institucionalmente e que se manifesta na construção de um mundo possível”. Sodré (2009, p.71) revela que há uma diferença entre notícia e acontecimento. A notícia factual constitui-se como um relato (micronarrativo) de um acontecimento inscrito na realidade histórica e suscetível de comprovação, "à emergência da ocorrência ou fato bruto, segue-se a busca social de sentido para ela, e, finalmente, a sua neutralização explicativa pela narrativa do acontecimento" (SODRÉ, 2009, p.71). Sem dúvida, a narrativa noticiosa restaura uma falha, confirma a previsibilidade da ordem e também instaura um questionamento do Jornalismo como forma de conhecimento.

A perspectiva funcionalista indica o caráter socializante dos relatos jornalísticos, mas sugere que o jornalismo tem se desenvolvido para atender às demandas de um volume enorme de informações da sociedade capitalista, reproduzindo valores dominantes da sociedade. No entanto, ainda que o jornalismo expresse e atenda aos interesses hegemônicos, possui características próprias como forma de conhecimento social e ultrapassa, por sua potencialidade histórica, a mera funcionalidade ao sistema capitalista, é um processo que implica em um fazer e em um saber específicos (GENRO FILHO, 1987, p.20, p.67-68). O Jornalismo é capaz de revelar aspectos da realidade social cotidiana que não são alcançados por formas de conhecimento mais prestigiadas em nossa cultura, ainda que os discursos jornalísticos sejam sempre condicionados pelo modo particular como os jornalistas vêem o mundo, a rotina produtiva e os objetivos das organizações onde trabalham, as condições técnicas e econômicas para a realização de suas tarefas e os conflitos de interesses que estão implicados na circulação social da informação (Meditsch, 1997, p.10). Um dos principais problemas do Jornalismo como forma de conhecimento é a falta de transparência destes condicionantes. O Jornalismo reproduz a sociedade em que está inserido, suas desigualdades e suas contradições. No entanto, nenhum modo de conhecimento disponível está imune a isto.

A tecnologia também segue diferentes tendências de desenvolvimento, usos e significados, e é apropriada pelas pessoas conforme seus hábitos e necessidades. Não determina a sociedade,
Um dos principais problemas do

Jornalismo como forma de conhecimento é a falta de transparência destes

condicionantes.

- Jornalismo reproduz a sociedade em que está inserido, suas desigualdades e suas contradições.

No entanto, nenhum modo de conhecimento disponível está imune a isto 
mas reproduz suas diferenças e seus diversos modos de existência e de expansão, gerando uma profunda transformação na contemporaneidade (Castells, 2007, p.246). As tecnologias digitais intervêm nas rotinas produtivas do jornalismo e geram novos formatos de notícia como o texto informativo não linear marcado pela multimidialidade e pela interatividade. No hipertexto o leitor "navega" priorizando os links que desejar, e se esta perspectiva não transforma o estilo jornalístico marcado pela concisão, pela síntese, pela clareza e a objetividade (SODRÉ, 2009, p.208) provoca mudanças nos modos de apropriação dos relatos jornalísticos, sobretudo no telejornalismo e na construção de notícias que utilizam a linguagem audiovisual e recursos multimídia na internet, podendo gerar possibilidades de atribuir outros sentidos à experiência da realidade social representados e construídos nas enunciações dos acontecimentos. A digitalização não é condição para a convergência, mas promove uma aceleração antes impensada na vida social. Para Jenkins (2008, p.27-28) a convergência não deve ser compreendida apenas como um processo tecnológico que une múltiplas funções dentro dos mesmos aparelhos porque também define transformações mercadológicas, culturais e sociais, e dependende da participação ativa dos consumidores. Segundo Manovich (2001), novas experiências de linguagens são geradas a partir da união de banco de dados às narrativas. E o hipertexto também traz novas possibilidades de escrita e de leitura (JOHNSON, 2001, p.83-84). Compreender como o ciberespaço oferece outras maneiras de elaborar as narrativas, estabelecendo relações entre cinema, jogos e literatura é uma proposta de Murray (2003), que descreve a transformação de uma mídia para outra como um "processo evolutivo". Há quase sessenta anos, quando a TV era inaugurada no Brasil, as notícias eram lidas ante uma câmara. Levou anos para o aprimoramento de novas técnicas que tirassem proveito da nova mídia: filmagens com câmeras mais leves e em maior quantidade, transmissões ao vivo de diferentes locações numa mesma cobertura, vídeos gravados, artes e gráficos. Hoje, as fronteiras formais e materiais entre os suportes e as linguagens foram dissolvidas, as notícias são compostas das mais diversas fontes. A diferenciação entre os meios já não é tão evidente e as novas tecnologias permitem inovação e geração de múltiplos conteúdos simultâneos e diferentes. Mas, as passagens que se operam entre a fotografia, o cinema, o vídeo e as mídias digitais são marcadas por tensões e ambiguidades (MACHADO, 2007, p.77). A consciência crítica dos efeitos das novas tecnologias demanda uma reflexão para onde toda essa hibridização nos conduz nas rotinas produtivas do jornalismo, até porque a função da mídia de organizar e hierarquizar a realidade nos relatos dos acontecimentos ocorre de forma mais expressi-
Hoje, as fronteiras formais e materiais entre os suportes e as linguagens foram dissolvidas, as notícias são compostas das mais diversas fontes. A diferenciação entre os meios já não é tão evidente e as novas tecnologias permitem inovação e geração de múltiplos conteúdos simultâneos e diferentes 
va e impactante quando se faz uso da linguagem audiovisual, um campo da comunicação complexo na construção e ressignificação de sentidos (VIZEU, 2008, p.7-14).

Há muitas críticas e indagações sobre a exploração dos novos formatos informativos e sobre o grau de inovação dos sites jornalísticos na apuração e no tratamento das notícias. Frente ao mito, se apresenta uma modesta realidade porque o hipertexto raramente é utilizado como recurso narrativo no ciberespaço (SALAVERRÍA, 2005, p.520). Apesar de todos os avanços tecnológicos, a imprensa online ainda busca uma identidade própria. As webtus representam a terceira fase de desenvolvimento do webjornalismo audiovisual caracterizada por projetos editoriais de informação e entretenimento produzidos e dirigidos exclusivamente para a internet (NOGUEIRA, 2005). Os sites que produzem conteúdos exclusivos para o meio digital, porém, ainda experimentam os primeiros passos em direção a uma gramática própria, que carecem da experimentação de novas formas de narrativa com aproveitamento de recursos multimídia e de interatividade, capazes de proporcionar ao usuário a oportunidade de navegar e percorrer um relato noticioso mais do que simplesmente acompanhá-lo de modo linear, e de estabelecer uma relação colaborativa com os portais jornalísticos referente a matérias factuais. Além disso, a difusão de conteúdos audiovisuais também é ainda muito restrita por causa da capacidade da rede e assistimos a uma implantação cada vez mais intensa de mecanismos para o protecionismo de dados e informações em vídeo. O próprio conceito de interatividade, segundo Primo (2007, p.17-54), ainda é impreciso porque o modelo teórico do processo de comunicação na web, ainda guarda para o internauta a restrição do lugar do consumidor, aquém da função de receptor, capaz de ser valorizada quando o diálogo é efetivamente potencializado. Mielniczuk (2001) destaca que a interatividade se baseia na ação comum que ocorre entre dois ou mais agentes; na capacidade igualitária de ação entre os agentes e na existência de imprevisibilidade das ações. Para a autora, situações que não contemplam esses requisitos não são interativas e sim reativas. Verifica-se ${ }^{3}$ que apesar de existir espaço para a publicação de vídeos de usuários nos portais jornalísticos mais acessados no país, a maior parte dos textos audiovisuais colaborativos é clipes musicais, traillers de filmes e curiosidades. Os usuários também quase não produzem e raramente publicam arquivos de áudio e vídeo na forma de notícias nas redes colaborativas. De qualquer modo, Islas (2007) sugere que há tendência para uma interatividade plena, ou seja, uma relação simétrica e intercambiável entre produção e recepção, proporcionando partilha e troca de informações e de conteúdos jornalísticos marcados pela multimidialidade porque

3 "Um Panorama da Produção Jornalística Audiovisual no Ciberespaço, as experiências das redes colaborativas". Trabalho apresentado no GT Estudos de Jornalismo - Compós 2009 . 
a alfabetização digital tem transformado os cibernautas ordinários em prosumidores em inglês, prosumer procede da fusão de duas palavras: "producer" (produtor) e "consumer" (consumidor), e o advento dos prosumidores antecipa o fim da era dos meios massivos e da produção centralizada de imagens, uma vez que o ambiente digital estimula a criatividade e a autonomia (ISLAS, 2007, p.74).

Diferentes experiências informativas no ciberespaço são analisadas, a partir da hipertextualidade, uma forma não linear de estruturar e acessar informações numa plataforma digital promovendo relações com outros dados por meio de links; da interatividade, considerando que os membros da audiência podem iniciar e desenvolver ações plenas de comunicação tanto com o meio quanto com outros usuários; e da multimidialidade, que indica a integração em um mesmo suporte de diferentes formatos e linguagens (Albornoz , 2007, p.54). É claro que a qualidade dos conteúdos informativos não depende dessas categorias ( Salaverria, 2005, p.517). Um conteúdo de um site jornalístico pode ser excelente sem recorrer a essas possibilidades, até porque um texto com infinidades de recursos pode carecer de valor informativo. Mas, essas características narrativas das notícias no ciberespaço apresentam novas construções discursivas que devem ser avaliadas e exploradas. As recentes mudanças provocadas pelas novas tecnologias de comunicação têm introduzido ainda diferentes possibilidades de tratamento da imagem e mudanças significativas no tempo e na velocidade de produção, armazenamento, distribuição e consumo de informações televisuais. Os relatos jornalísticos na TV e na web estão mesmo cheios de novidades que desestabilizam o funcionamento da tradicional economia da imprensa. Em momentos de profundas transformações e rupturas surgem novas perspectivas que devem ser analisadas. As práticas jornalísticas audiovisuais experimentam mudanças expressivas nos formatos de notícias que demandam reflexões críticas consistentes para valorizar o jornalismo como forma de conhecimento e para a democratização da sociedade. A sistematização de parâmetros de qualidade se constitui como referência relevante e questão complexa porque as notícias audiovisuais constituem lugar de referência expressivo na cultura da mídia e na organização da vida social.

\section{Práticas jornalísticas de qualidade na TV e na Internet}

A qualidade de relatos jornalísticos audiovisuais pressupõe diversidade de temas e de atores sociais, pluralidade de interpretações, inovações estéticas e contextualização dos acontecimentos (BECKER, 2008, p.357-367), o que o uso da convergência, necessariamente, não garante. Mas, o jornalismo, com base
As práticas jornalísticas audiovisuais experimentam mudanças expressivas nos formatos de notícias que demandam reflexões críticas consistentes para valorizar

o jornalismo como forma de conhecimento e para a democratização da sociedade 
na convergência entre texto, som e imagem em movimento, pode resultar em práticas mais inovadoras do que o atual jornalismo televisivo e praticado na web, proporcionando notícias mais críticas e criativas porque a quebra da leitura linear permite um jornalismo mais participativo ${ }^{4}$ (CANAVILHAS, 2001, p.4-5). O leitor/ espectador/ usuário tem possibilidades de escolher um caminho de uma navegação fluida sem interrupções, em acordo com os seus interesses. Um dos aspectos que distingue uma cobertura jornalística de qualidade é a abordagem ou o ângulo original e inesperado da notícia. O telespectador é limitado a seguir a história como ela é relatada sob determinado enfoque, seguindo um curso previamente definido pelo jornalista, ainda que negociando os sentidos das enunciações. No webjornalismo a situação é um pouco diferente. $\mathrm{O}$ uso de hiperlinks permite ao usuário construir no ciberespaço o seu próprio percurso na leitura, assim como a própria abordagem do fato transformado em notícia, se os editores também deixarem os fatos falarem por eles mesmos, explorarem outras formas de produção da notícia e disponibilizarem o mais amplo conjunto de informações possíveis. (CANAVILHAS, 2006, p.4). Além disso, na televisão, o texto da notícia (voz-off) deve ser casado com a imagem. De modo geral, não há concorrência semântica entre esses dois elementos da informação. Texto e imagem são um só produto e não têm significado quando separados. O video no webjornalismo pode não funcionar apenas um complemento da informação verbal como no caso da imagem informativa televisual, que desperta curiosidade e incerteza amparadas e organizadas pelo comentário verbal ou pelo texto off (CANAVILHAS, 2006, p.8) .

As definições das práticas jornalísticas de qualidade na televisão e na web, entretanto, ainda não estão claras e a sistematização de parâmetros mais precisos é questão relevante nas reflexões críticas sobre a função do jornalismo na atualidade, especialmente como forma de conhecimento. São referências importantes para indicar como uma produção televisiva de qualidade pode quebrar determinadas regras discursivas e temáticas, transformando e mesclando gêneros, inserindo diferentes pontos de vista na construção da narrativa. Permite investigar ainda o modo como a TV intervém, através da sua mediação, em diferentes dimensões na agenda política da nação, e como um produto cultural criado no interior de uma indústria da comunicação pode ser esteticamente inovador e apresentar abordagens interessantes sobre assuntos do cotidiano, a ponto de gerar novos modos de perceber o Brasil e o mundo, atribuindo outros sentidos à realidade social cotidiana. Funcionam, efetivamente, como diretrizes para a produção de relatos jornalísticos mais críticos e criativos na TV e na Internet, aproveitando o potencial da multimidali- 
dade e da interatividade. A qualidade em televisão, porém, é, um conceito de difícil definição porque envolve um conjunto de valores que são, muitas vezes, difíceis de ser mensurados, e não é uma questão de consenso. Depende muitas vezes do ponto de vista do qual a qualidade é avaliada. Mas, a definição de estratatégias e critérios da qualidade em TV pode ser problematizada. O trabalho de Arlindo Machado (2003) é um marco dos estudos televisivos no Brasil porque reenquadra a questão da qualidade a partir da proposta de que a TV é um dos grandes fenômenos culturais do nosso tempo, e deve ser estuda da partir de obras criativas de referência produzidas nos seus mais de 50 anos de existência, apesar de todas as produções popularescas e mercadológicas. O autor contrapõe ao conceito de "fluxo televisual" de Raymond Williams (1979), a ideia de programa (MACHADO, 2003, p.28-29) porque permite uma abordagem mais seletiva e qualitativa, e revela que "a qualidade pode estar simplesmente na diversidade, o que significa dizer que a melhor televisão seria aquela que abrisse oportunidades para o mais amplo leque de experiências diferenciadas." (MACHADO, 2003, p.30). E é justamente o princípio de diversidade que nos remete a reflexão sobre um jornalismo audiovisual de qualidade.

Diversidade é uma questão fundamental na política pública e em uma reflexão crítica sobre as relações entre democracia e sistemas de mídia porque, como aponta Hughes (2009), as visões de mundo e os estilos de vida representados na comunicação massiva tendem a influenciar valores e práticas essenciais na vida social. No Brasil e na América Latina os sistemas de mídia são alguns dos setores de negócios mais concentrados (os dados apurados sobre os investimentos publicitários na mídia brasileira são impactantes ${ }^{5}$ ), e coexistem com frágeis setores e organizações públicas e civis. Parte expressiva da população não tem acesso às tecnologias midiáticas interativas, tampouco à Internet ${ }^{6}$. Além disso, os conteúdos das transmissões televisivas tendem a transmitir agendas e perspectivas de grupos de maior poder, geralmente apresentados como valores e princípios naturais ou resultantes do senso comum. A diversidade de programas e conteúdos destinados a audiências distintas e a descentralização dos meios, certamente, são essenciais para o fortalecimento da democracia e para a qualidade das informações jornalísticas. Afinal, como já destacou Ramonet (apud BENEDETI, 2009, p.51), o jornalismo tem o potencial de instruir e formar cidadãos, uma vez que "de uma informação de qualidade depende sua (do público) maior ou menor participação na vida cívica - e consequentemente a qualidade na democracia”. Schudson (1998, p.30) acredita que a mídia não pode criar cidadãos informados sozinha, mas pode colaborar mais com a democracia. A imprensa sempre esteve ligada à luta

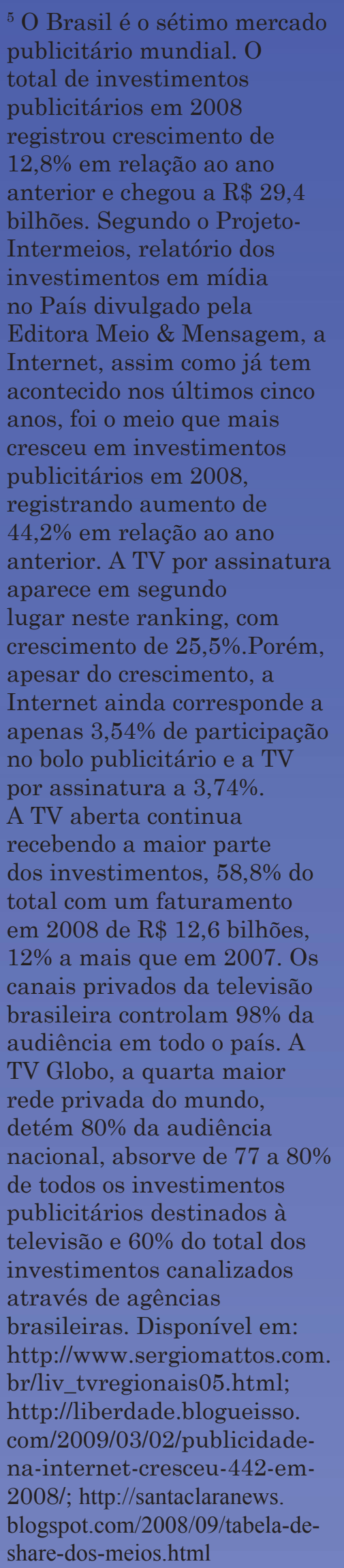


política, não há poder sem imprensa nem imprensa sem poder porque todo governo fez e continua fazendo uso da imprensa e de outras formas de persuassão para criar melhores condições de governabilidade. No entanto, a imprensa ainda é igualmente um dos principais instrumentos da oposição e da resistência política em qualquer época. Ao mesmo tempo em que a imprensa é uma instituição historicamente vinculada à vigilância pública pelo poder em exercício para a manutenção da ordem instituída, é um instrumento do exercício da democracia (Motta (2002, p.13), o que reafirma a demanda de uma sistematização de parâmetros de qualidade referentes às práticas jornalísticas na atualidade.

Outro aspecto que impõe uma necessidade de repensarmos essa questão são as novas relações estabelecidas com o tempo e o espaço mediadas pelas tecnologias digitais e pelos relatos jornalísticos na sociedade contemporânea. $\mathrm{O}$ advento e o desenvolvimento da telecomunicação na segunda metade do século XIX trouxe, como explica Thompson (1995, p.36-41) uma disjunção entre o espaço e o tempo, o distanciamento espacial deixou de implicar o distanciamento temporal. Informação e conteúdo simbólico presente nos produtos da indústria da mídia puderam ser transmitidos para distâncias cada vez maiores num tempo cada vez menor. Tornou-se possível experimentar eventos simultâneos, apesar de acontecerem em lugares muito diferentes. O desenvolvimento de novos meios de comunicação afetou as maneiras pelas quais os indivíduos experimentam a vida social. Antes do desenvolvimento da indústria da mídia, a compreensão do passado e de lugares distantes, como também do espaço e da continuidade histórica das comunidades a que pertenciam, era constituída pelas tradições orais em conversas cotidianas. As interações face a face não deixaram de ter um lugar na sociedade, mas o desenvolvimento dos meios criou uma compreensão do mundo, modeladas por palavras e imagens transmitidas pela mídia. (THOMPSON, 1995, p.38).

Bauman (2001, p.128-129) revela que a história do tempo começou com a modernidade - o tempo em que o tempo tem uma história. Explica que o começo da era moderna pode ser associado a várias facetas, mas deve ser compreendido como a emancipação do tempo em relação ao espaço e pela sua subordinação à inventividade e à capacidade técnica humanas. Na contemporaneidade o espaço pode ser atravessado em " tempo nenhum", perdendo seu valor estratégico. Bauman (2001, p.138) ainda questiona se agora há ainda um tal tempo como um agregado de momentos como o conhecemos, sugerindo que o desaparecimente do espaço poderia ser uma tendência do tempo para a auto-aniquilação.A instantaneidade aparentemente se refere a um movimento muito rápido e a um tempo muito curto, mas de fato denota ausência

${ }^{6} \mathrm{O}$ número de pessoas com acesso à internet no Brasil já ultrapassou 40 milhões de pessoas, $22,5 \%$ de uma população de 184 milhões de habitantes acessam a web, menos da metade de todos os brasileiros. Disponível em : www1.folha.uol.com.br/folha/ informatica/ult124u416776. shtml 
de tempo. E se todas as partes do espaço podem ser atingidas, nenhuma tem valor especial, logo não haveria razão para se preocupar em garantir o direito de acesso a qualquer uma delas (BAUMAN, 2001, p.136). Se essa reflexão for aplicada na relação entre produção, circulação e consumo de informações jornalísticas, poderíamos dizer que a demanda do imediatismo e da inovação que marca a superabundância de notícias gera relatos cada vez mais enxutos e descartáveis, a instantaneidade tende a esvaziar os conteúdos, até porque a duração de uma apuração consistente de uma fato social é bem maior do que o tempo de transmissão e publicação do relato do acontecimento e está em desacordo com a lógica da instantaneidade e do mercado. Além disso, se todas as notícias se tornam relativamente iguais como as referidas partes do espaço, só faria sentido acessá-las se apresentassem um atributo de qualidade mais evidente, substituindo o valor da instantaneidade como marca da temporalidade do relato jornalístico pela proximidade de fontes de incerteza e de diversidade. Nesse sentido, quando a compreensão do tempo na contemporaneidade se transforma, somos provocados por algumas outras inquietações: Que tipo de discurso jornalístico é preciso construir frente as novas configurações do tempo? Que responsabilidades a prática jornalística deve assumir para que nossos jornais e TVs sejam menos ocupados por fofocas sobre celebridades públicas ou por puro entretenimento e pela publicidade? Quais seriam as características necessárias para que uma informação jornalística fosse capaz de promover alguma consciência crítica sobre uma determinada realidade histórica? As novas relações entre tempo-espaço, portanto, também demandam outras referências sobre as práticas jornalísticas que possam reafirmá-las como formas de conhecimento superando a homogeneidade dos discursos e privilegiando o reconhecimento das diferenças.

A própria hibridização dos meios marcada por processos interativos e multimidáticos e a quebra de uma leitura linear das mensagens, como já referido, também implica na sistematização de parâmetros de um jornalismo de qualidade de modo relevante porque as emissoras de televisão e os portais jornalísticos comprometidos com a exploração dos potenciais da web podem buscar aspectos originais e criativos na apuração e na construção das notícias, incorporando elementos simbólicos constitutivos de valores e identidades diferenciados, promovendo um jornalismo mais contextualizado, mesmo que ainda limitado pelas novas rotinas de produção e atribuições impostas aos profissionais que trabalham na TV e na Internet.

Os parâmetros de qualidade nas práticas jornalísticas, porém, suscitam distintas definições e ainda estão sendo contruídos nas reflexões acadêmicas sem a ênfase necessária. Não devemos
As novas relações entre tempoespaço, portanto, também demandam outras referências sobre as práticas jornalísticas que possam reafirmálas como formas de conhecimento superando a homogeneidade dos discursos e privilegiando 0 reconhecimento das diferenças 
perder de vista a incorporação de sistemas descentralizados e a busca da diversidade e da pluralidade nas representações jornalísticas dos fatos, especialmente na web. Trabalhar informações exclusivas, a apuração dos conteúdos e fontes distintas garante a qualidade da informação jornalística. Mas, não podemos esquecer que o exercício do jornalismo também é restringido por outros fatores. Reconhecer esses limites não significa ignorar as problemáticas geradas pelas atividades jornalísticas sem compromisso com os interesses da sociedade. Benedeti (2009, p.12) sugere que critérios de qualidade podem proporcionar um aperfeiçoamento da prática jornalística. Afinal, como argumenta Guerra (2007), a instituição jornalística representa um conceito de atividade voltada para atingir um objetivo essencial que é colocar as pessoas em contato com fatos e ideias. Para tanto, é imprescindível que haja objetividade; relevância; e pluralidade (GUERRA, 2007). Num estudo de caso sobre a cobertura do Jornal Nacional nas eleições presidenciais de 2002, Porto (2005, p.142) revela, entretanto, que o processo de deliberação política ainda é caracterizado por pouca diversidade de acesso e enquadramentos.

\section{Considerações Finais}

A informação de fatos relevantes para a sociedade é ponto central da atividade jornalística e pressupõe um respeito ao interesse público, um compromisso com a divulgação do que sirva para benefício comum, ou do que se imponha como necessidade coletiva. As relações das empresas de comunicação com os poderes públicos e privados limitam a construção de relatos jornalísticos, assim como as condições de produção, e os recursos financeiros disponíveis para serem investidos em matérias mais elaboradas. Não podemos compreender o jornalismo como uma atividade filantrópica, a notícia é um produto, mas há possibilidade de trabalhar os conteúdos jornalísticos, garantindo lucros, com notícias mais contextualizadas. Afinal, as transformações podem originar-se parcialmente no discurso (Fairclough , 2001, p.92), e os discursos jornalísticos representam e constituem a esfera pública, o princípio de organização que permite às pessoas se unirem politicamente. Com base no pensamento de Habermas (2003, p.283-284), o termo jornalismo público e o emergente jornalismo participativo se justificariam pela definição de um modelo de prática jornalística que permitiria indivíduos (reivindicantes de uma esfera pública democrática) participar, se reunindo em público num espaço midiático supostamente aberto para discutir a sociedade, buscar representação e apreender maneiras de exercer sua cidadania. Mas, nem sempre os ângulos determinados na produção das reportagens com seus diferentes enquadramentos que conferem significados à realidade
Observamos que também no ciberespaço uma produção jornalística de qualidade implica em diversidade de acesso e conteúdo. Mas, essas premissas demandam novas investigações e defínições de percursos teóricos e metodológicos mais precisos referentes às singularidades e às inovações de narrativas jornalísticas audiovisuais híbridas no meio digital 
cotidiana, às relações sociais e às instituições estão amparados na busca da diversidade. Os processos de construção de discursos sobre os fatos transformados em acontecimentos, que servem à formação da opinião pública, os modos de elaboração das notícias resultante da cultura profissional, das rotinas produtivas, dos critérios de noticiabilidade, dos valores-notícia (TRAQUINA, 2005, p.69-101), e dos códigos e regras particulares do campo da comunicação têm sido examinados pelos estudos de newsmaking. $\mathrm{Na}$ análise da informação jornalística audiovisual, a visibilidade da experiência social tem sido associada a um critério de análise importante, o da tematização (Vilches, 1995, p.36) - uma forma de seleção que promove a atenção e o interesse público sobre alguns temas e valores em detrimento de outros. Herreros (2003, p.180) afirma, porém, que é necessário realizar uma releitura dos critérios de noticibialidade criados em época de demandas sociais e contextos históricos diferenciados, os quais precisam estar sintonizados com a contemporaneidade, revelando o esforço e a contribuição de todos para a vida social e o desenvolvimento de um país. Interessados em contribuir neste debate redefiniram-se critérios que pudessem servir como referência para agregar valor simbólico às narrativas jornalísticas audiovisuais e enriquecer as representações das identidades locais e nacionais (BECKER e GONZALES, 2009). Dois desses critérios - a criatividade no uso da linguagem audiovisual e a interatividade, têm servido de diretrizes para a construção do conceito jornalismo audiovisual e para realizar investigações sobre o potencial das novas tecnologias na elaboração de relatos mais críticos e criativos na TV e na Internet. Observamos que também no ciberespaço uma produção jornalística de qualidade implica em diversidade de acesso e conteúdo. Mas, essas premissas demandam novas investigações e definições de percursos teóricos e metodológicos mais precisos referentes às singularidades e às inovações de narrativas jornalísticas audiovisuais híbridas no meio digital.

\section{Referências}

ALBORNOZ, Luis A. Periodismo digital: Los grandes diários em la Red. Buenos Aires: La Crujía, 2007.

ALSINA, Miquel Rodrigo. A Construção da Notícia. Petrópolis: Editora Vozes, 2009.

BAUMAN, Zygmunt. Modernidade Líquida. Rio de Janeiro: Jorge Zahar, 2001.

BECKER, Beatriz. Diversidade e Pluralidade: Desafios da Produção de um telejornalismo de qualidade. In: BORGES, Gabriela; REIA-BAPTISTA, (orgs.). Discursos e Práticas de Qualidade na Televisão. Lisboa: Novos Horizontes, 2008, p.357-367.

BECKER, Beatriz e GONZALES, Celeste. The past and the future of Bra-

Estudos em Jornalismo e Mídia - Ano VI - n. 2 pp. 95 - 111 jul./dez. 2009 
zilian television news. In: Journalism: Theory, Practice and Criticism, 2009, vol.10, p.45-68. Disponível em SAGE Journals Online < http://jou. sagepub.com/cgi/reprint/10/1/45>.

BECKER, Beatriz e TEIXEIRA, Juliana. Um Panorama da Produção Jornalística Audiovisual no Ciberespaço, as experiências das redes colaborativas. XVIII Encontro da Compôs. GT "Estudos de Jornalismo". Belo Horizonte, MG: PUC-MG, junho de 2009. Disponível em: http://www.compos. org.br/data/trabalhos_arquivo_coxXSSt2GSR16.pdf.

BENEDETI, Carina Andrade. A qualidade da informação jornalística - do conceito à prática. Florianópolis: Insular, 2009.

BRAIT, Beth ( org.), Bakhtin Conceitos-Chave, São Paulo, Editora Contexto, 2005.

CANAVILHAS, João. Webjornalismo, considerações gerais sobre jornalismo na web. 2001.

Disponível em http://bocc.ubi.pt/pag/canavilhas-joao-webjornal.pdf .

The news on webjournalism. A reading on image and architecture of information. 2006. Disponível em http://bocc.ubi.pt/pag/ canavilhas-joao-the-news-on-webjournalism.pdf .

CASETTI, Francesco; CHIO, Frederico di. Análisis de la televisión - instrumentos, métodos y prácticas de investigación. Barcelona: Padós, 1999.

CASTELLS, Manuel. Mobile communication and society - a global perspective. London, England: The MIT Press, 2007.

CIRNE, Lívia, FERNANDES, Marcelo, PÔRTO, Ed. Perspectivas da interatividade no telejornalismo da TV digital brasileira. In: SQUIRRA, Sebastião, FECHINE, Yvana (orgs.). Televisão digital, desafios para a comunicação. Porto Alegre: Sulina, 2009, p. 84-107.

DUARTE, Elizabeth Bastos. Á Guisa de Apresentação. In: JOST, François. Seis lições sobre televisão. Coleção Estudos sobre o audiovisual. Porto Alegre: Sulina, 2004.

FAIRCLOUGH, Norman. Discurso e mudança social. Brasília: UNB, 2001

GENRO FILHO, Adelmo. O segredo da pirâmide - para uma teoria marxista do jornalismo. Porto Alegre, Tchê, 1987. 230 pp.

GIDDENS, Anthony. Mundo em descontrole - o que globalização está fazendo de nós. Rio de Janeiro: Record, 2003.

GUERRA, Josenildo Luiz. Monitoramento de Cobertura e Produção Experimental Monitorada: pesquisa aplicada voltada para a qualificação de produtos e processos jornalísticos. $5^{\circ}$ Encontro Nacional de Pesquisadores em Jornalismo - SBPJor - Universidade Federal de Sergipe - 15 a 17 de novembro de 2007.

HABERMAS, Jürgen. Mudança estrutural da esfera pública. Tradução de Flávio R. Kothe. Rio de Janeiro:Tempo Brasileiro, 2003.

HERREROS, Mariano Cebrián. Información Televisiva. Madrid: Editorial Síntesis, 2003.

HUGHES, Sallie. Media Diversity and Social Inequality in Latin America. Congresso de 2009 da LASA (Associação de Estudos Latino-Americanos), 
no Rio de Janeiro, Brasil, de 11 a 14 de junho de 2009.

ISLAS, Octavio. La sociedad de la ubicuidad, los prosumidores y um modelo de comunicación para comprender la complejidad de la comunicaciones digitales. In: Revista Latinoamericana de Ciencias de la Comunicación. Ano IV, número 7, julio/deciembre, 2007, p.68-77.

JENKINS, Henry. Cultura da convergência. Tradução de Susana Alexandria. São Paulo: Aleph, 2008.

MACHADO, Arlindo. Arte e Mídia. Rio de Janeiro: Jorge Zahar, 2007. A televisão levada a sério. São Paulo: SENAC, 2003.

MARTÍN-BARBERO, Jesús e REY, Germán. Os Exercícios do Ver. Hegemonia audiovisual e ficção televisiva. São Paulo: SENAC São Paulo, 2001.

MARTINS DA SILVA, Luiz. Jornalismo público: o social como valor-notícia. In: $11^{\circ}$ Compôs ECO - UFRJ. GT Políticas e Estratégias de Comunicação. Rio de Janeiro: SENAI, 2002.

MEDISTSCH, Eduardo. O Jornalismo é uma forma de conhecimento?. Universidade Federal de Santa Catarina: 1997 - Disponível em http://bocc. ubi.pt/pag/meditsch-eduardo-jornalismo-conhecimento.pdf - Acessado em 20 de dezembro de 2007.

MIELNICZUK, Luciana. Considerações sobre interatividade no contexto das novas mídias. 2001. Disponível em: http://www.facom.ufba.br/jol/ pdf/2001_mielniczuk_interatividadenovas.

MORIN, Edgar. Os sete saberes necessários à educação do futuro. Trad. Catarina Eleonora F.da Silva e Jeanne Sawaya - $8^{a}$ edição. São Paulo: Cortez; Brasília: Unesco, 2003. Disponível em http://ww2.prefeitura.sp.gov. br/secretarias/meio_ambiente/umapaz/files/Morin.pdf. Acessado em 28 de junho de 2008.

MOTTA, Luiz Gonzaga. Imprensa e Poder. Brasília: Editora Universidade de Brasília, 2002.

MURRAY, Janet H. Hamlet no Holodeck: o futuro da narrativa no ciberespaço. Tradução de Elissa Khoury Daher e Marcelo Fernandez Cuzziol. São Paulo: Itaú Cultural/Unesp, 2003.

NOGUEIRA, Leila. O web Jornalismo audiovisual: uma análise de notícias no UOL News e na TVUERJ on-line. Dissertação (Mestrado), Universidade Federal da Bahia, orient.: Prof.Dr. Elias Machado, 2005.

PINTO, Milton José. Semiologia e imagem. In: BRAGA, José Luiz; NETO, Antônio Fausto; PORTO, Sérgio Dayrell (orgs.). A encenação dos sentidos; mídia, cultura e política. Rio de Janeiro: Compós, Diadorim, 1995, p.141157.

PRIMO, Alex. Interação mediada por computador. Porto Alegre: Sulina, 2007.

PORTO, Mauro. The principle of diversity in Journalism. Brazilian Journalism Research, SBPJor, V.1, N.1, semester 1,UNB, 2005, p.135- 153

SALAVERRÍA, Ramón. Hipertexto periodístico: mito y realidad. 2005. Disponível em: http://cicr.blanquerna.url.edu/2005/Abstracts/PDFsComunicacions/vol1/05/SALAVERRIA_Ramon.pdf.

SCHUDSON, Michael. Creating Public Knowledge. In DENNIS, Everette 
E. \& SNYDER, Robert W. Media \& Democracy. New Brunswick (EUA) e Londres: Transaction Publishers, 1998, pp. 29-34.

SODRÉ, Muniz. A Narração do Fato - notas para uma teoria do acontecimento. Petrópolis, RJ: Vozes, 2009.

VATTIMO, Gianni. A sociedade transparente. Relógio D’água Editores, 1992.

VILCHES, Lorenzo. Manipulación de la Informacion Televisiva. Ediciones Paidós, Barcelona, 1995, 380p.

VIZEU, Alfredo (org). A sociedade do telejornalismo. Petrópolis, RJ: Vozes, 2008.

O lado oculto do telejornalismo. Florianópolis: Calandra,

2005

THOMPSON, John B. A mídia e a modernidade - uma teoria social da mídia. Petrópolis, RJ: Vozes, 1995.

TRAQUINA, Nelson. Teorias do Jornalismo, vol.II. Florianópolis/SC: Insular, 2005.

Recebido em 22 de agosto de 2009

Aprovado em 29 de setembro de 2009 